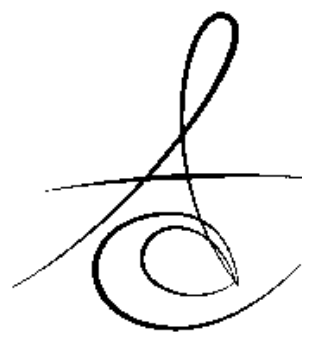

\title{
3 FARKLI DİŞETİ RETRAKSİYON YÖNTEMİNİN HASTA KONFORU AÇISINDAN KARŞILAŞTIRILMASI: PİLOT ÇALIŞMA
}

\section{COMPARİNG THE EFFECTİVENESS OF THREE DİFFERENT RETRACTION METHODS ON PATIEENT'S COMFORT: A PILOT STUDY}

\author{
Yrd. Doç.Dr.Orhun EKREN * Ar.Gör. Dr.Nihan ÇERÇĩ
}

Makale Kodu/Article code: 2794

Makale Gönderilme tarihi: 15.04 .2016

Kabul Tarihi: 12.05 .2016

\section{öz}

Amaç: Bu çalışmanın amacl; 3 farklı retraksiyon yönteminin hasta konforu, dişeti yer değiştirme etkinlikleri, kanama, hassasiyet ve dişeti çekilmesi yönünden Vizüel Analog Skalası (VAS) kullanılarak karşılaştııılmasıdır.

Materyal ve Metod: Sabit protez intiyacı olan, sağlıkl dişeti kriterlerine sahip toplam 110 birey çalışmaya dâhil edilmiş ve gruplara rastgele dağıtılmıştır. İlk gruptak hastalara geleneksel retraksiyon kordu ile mekanik retraksiyon yöntemi, 2. grupta kord ve alüminyum klorid $\left(\mathrm{AlCl}_{3}\right)$ solüsyonu kombinasyonu ve 3. Grupta ise retraksiyon pastası ile dişeti retraksiyonu uygulanmıştır. İlk seansta dişler subgingival oluk (chamfer) bitiş çizgisi uygulanarak prepare edilmiş ve aynı seansta geçici restorasyonlar yapılmıştır. Ölçü seansı için 7 gün sonraya randevu verilmiştir. Hasta konforu retraksiyon seansında 7 soru, retraksiyon sonrasında ise 1,7 ve 28 . günlerde 7 soru sorularak ve alınan cevaplar ile değerlendirilmiştir. Dişeti yer değiştirme etkinliği diş hekimi tarafından VAS kullanılarak değerlendirilmiş, retraksiyon sonrası kanama görülen diş sayıları kaydedilmiştir. Sonuçların istatistiksel analizinde Kruskal-Wallis, Mann-Whittney $\mathrm{U}$, Ki kare testleri ve Bonferroni doğrulama testi kulllanıldı $(a=0,05)$.

Bulgular: Karşılaştırılan yöntemler arasında dişeti yer değiştirme etkinliği, çalışma süresi, hassasiyet, işlem sonrası kanama ve hasta konforu açısından gruplar arasında istatistiksel olarak anlamlı fark bulunmuştur $(p<0,001)$. Retraksiyon pastası grubu çalışma süresi ve hasta konforu açısından daha başarılı bulunmuştur $(p<0,001)$. Hassasiyet tüm gruplarda 7. ve 28. Günlerde azalma göstermiştir. Kord ve $\mathrm{AlCl}_{3}$ grubu yer değiştirme etkinliği açısından daha başarılı bulunmuştur $(p=0,005)$. Retraksiyon sonrası kanama görülen en fazla diş sayıs geleneksel kord grubunda görülmüştür $(p<0,001)$. Retraksiyon pastasında diğer gruplara göre daha az dişte dişeti çekilmesi görülmüştür $(p<0,001)$.

Sonuç: Kordsuz teknik (retraksiyon pastası) çalışma süresi, kanama, hassasiyet, postoperatif ağrı açısından diğer yöntemlere göre daha konforlu ve klinik kullanımda kolay uygulanabilir bulunmuştur. Mevcut çalışma sonuçlarına göre retraksiyon pastası yeterli diş eti yer değişimi sağlayarak klinik olarak kabul edilebilir ölçüler alınmasını sağlayabilmiştir.

Anahtar kelimeler: Dişeti retraksiyonu, kordsuz teknik, retraksiyon kordu, retraksiyon pastası, sabit protez

\begin{abstract}
Aim: The aim of this in vivo study was to evaluate patient's comfort, displacement quality, bleeding, gingival recession and sensitivity of 3 different gingival displacement methods using Visual Anologue Scale(VAS).

Material and methods: A total of 110 subjects with healty gingiva who needed fixed partial dentures were included in the study and divided into 3 groups randomly. After subgingival preparation with a chamfer finish line, group 1 received conventional retraction cord only, group 2 received cord with $\mathrm{AlCl}_{3}$ and group 3 received retraction paste prior to final impression. Immediatelly after provisinalisation, 7 questions were assessed at baseline and 7 questions were assessed at 1, 7, 28 days. The effectiveness of retraction methods were assesed by the same clinician according to VAS and the number of teeth with gingival bleeding after retraction were recorded. Data were analysed using Kruskal-Wallis, Mann-Whittney $\mathrm{U}, \mathrm{Ki}$ Square test and the Bonferroni correction test $(a=0,05)$.
\end{abstract}

Results: The displacement quality, working time, sensitivity, bleeding after application and patient's comfort were statistically significant among the groups $(p<0,001)$. Retraction paste showed better results for working time and patient comfort $(p<0,001)$. Sensitivity was reduced for all groups after 7 and 28 days. Cord and $\mathrm{AlCl}_{3}$ group showed better results for displacement quality $(p=0,005)$. The highest score for bleeding after application was in convantional cord group $(p<0,001)$. Group 2 and 3 were found to be comparable in terms of bleeding. Retraction paste group showed beter results in terms of gingival reccesion $(p<0,001)$.

Conclusion: Cordless technique (retraction paste) was clinically useful to save time and enhance patient comfort and it caused less bleeding, sensitivity, recession and postoperative pain. According to the results of the current study retraction paste is capable of retraction of gingiva for having clinically acceptable impressions.

Key words: Gingival retraction, cordless method, retraction cord, retraction paste, fixed partial denture

\footnotetext{
${ }^{*}$ Çukurova Üniversitesi, Diş Hekimliği Fakültesi, Protetik Diş Tedavisi AD.

* Bu Çalışma 47. Ced/Iadr Kongresinde Sözlü Sunum Olarak Sunulmuştur. 15-17 Ekim 2015, Antalya Bu Çalışma C.Ü Bap Tarafından Tdh-2015-3541 Numaralı Proje Olarak Desteklenmiştir
} 


\section{GİRİş}

Protetik tedavide; kaybedilen fonasyon, fonksiyon ve estetiğin kazandırılması kadar uygulanan restorasyonların doku uyumu ve devamlılığı da önemlidir. Sabit protez yapımında dokularla uygun ilişkilerin sağlanması, ölçü aşamasında yumuşak dokuların dikkatli bir şekilde kontrolünü gerektirir. Ölçü maddeleri yumuşak dokuları, sıvıları veya debrisi uzaklaştırmada yetersizdir ve tek başına uygun bir izolasyon sağlayamaz. Doğru bir model elde edebilmek için; debristen, sıvılardan uzak kuru bir alan yaratabilmenin yanında, ölçü alımında bitim çizgisinin açığa çıkarılması için yumuşak dokuların retrakte edilmesi gerekmektedir ${ }^{1-3}$.

Restorasyon marjinleri supragingival konumlandırımışsa rahatlıkla ideal bir ölçü alınabilir ve marjinal dişeti uyumu kolayca sağlanabilir. Eğer estetik gibi nedenlerden dolayı restorasyon kenarları subgingival bölgede konumlanırsa, serbest dişeti preparasyon bitim sınırının üzerini kapatacak ve net bir ölçü almak imkansız olacaktır. Bu nedenle serbest dişeti, ölçü öncesinde kontrol edilmeli ve dişeti retraksiyonu uygulanmalıdır ${ }^{1}$. Dişeti retraksiyonunun amacl $^{1}$.

1) Dişeti oluğunun geri dönüşümlü olarak horizontal yönde yer değiştirmesi

2) Dişeti oluğunun geri dönüşümlü olarak vertikal yönde yer değiştirmesi

3) Hemostaz sağlamaktır.

Gingival dokular lateral ve vertikal olarak yer değiştirebilir. Lateral retraksiyonda yer değiştiren dokular yırtılmalara karşı ölçüye yeterli hacim kazandırırken, vertikal retraksiyon dişin apikalindeki prepare edilmemiş kısmını açığa çıkarır. Böylece, prepare dişin tam ölçüsü alınabilir. ${ }^{1}$ Ölçü maddesinin sulkus bölgesinden yırtılmadan ve distorsiyona uğramadan uzaklaşması için retraksiyon sonrası sulkular genişliğin minimum 0,2 $\mathrm{mm}$ olması gerekmektedir ${ }^{4}$.

Periodontal dokulara zarar vermeden etkili bir dişeti retraksiyonu yapabilmek restorasyonun uzun dönem başarısı açısından oldukça önemlidir. Kullanılan retraksiyon yöntemleri ağrılı olmaları, anestezi gerektirmeleri, postoperatif dönemde ilgili dişte hassasiyet, ağrı, dişetinde çekilme gibi hasta konforunu olumsuz yönde etkileyecek dezavantajlara sahiptirler ${ }^{5}$. Son zamanlarda 'kordsuz teknik' olarak ortaya çıkan retraksiyon pastaları zaman kazandırmaları, uygulama kolaylığı, daha az invaziv olmaları ve bu şekilde hasta konforunu arttırmaları nedeniyle tercih edilmektedir. Retraksiyon pastası tabanca yardımıyla dişeti oluğu içerisine çok az basınçla $\left(0,1 \mathrm{~N} / \mathrm{mm}^{2}\right)$ enjekte edildiğinde, dişeti 2 dakika içerisinde $0,5 \mathrm{~mm}$ retrakte olmaktadır ${ }^{6}$. Piyasadaki retraksiyon pastaları hem mekanik hem de kimyasal retraksiyon sağlamaktadır. İçerdikleri alüminyum klorid $\left(\mathrm{AlCl}_{3}\right)$ nedeniyle hemostatik özelliğe sahiptir. Ayrıca içeriğindeki kaolinin dişeti oluğu sıvısıyla temas ettiğinde oluşan hidroskopik genleşmesi ile dişetinde 2 dakika içinde genişleme sağlamaktadır ${ }^{7,8}$.

$\mathrm{Bu}$ çalışmanın amacı; 3 farklı retraksiyon yöntemi olan konvansiyonal kord, kord ve alüminyum klorid solüsyonu, retraksiyon pastası tekniğini hasta konforu, dişeti yer değiştirme etkinlikleri, postoperatif kanama, hassasiyet ve dişeti çekilmesi yönünden Vizüel Analog Skalası (VAS) kullanılarak karşılaştırılmasıdır.

Çalışmanın hipotezi; 3 farklı retraksiyon yöntemi arasında hasta konforu, dişeti yer değiştirme etkinlikleri, postoperatif kanama, hassasiyet ve dişeti çekilmesi yönünden fark olmayacağıdır.

\section{Materyal ve Metod:}

Çalışmaya 2014-2015 yılları arasında Çukurova Üniversitesi Diş Hekimliği Fakültesi Protetik Diş Tedavisi Anabilim Dalı' na sabit protetik diş tedavisi intiyacıyla başvuran periodontal ve sistemik rahatsızlığı olmayan 18-65 yaş arası 110 birey dâhil edilmiştir. Çalışmaya dâhil edilen bireylerden Şekil 1 deki Hasta Takip Formu-1 ve 2 bilgileri alınmıştır. Bireylerin ilgili dişleri ilk seansta lokal anestezi altında uygun şemfer frezlerle basamak derinliği en fazla 0,5 $\mathrm{mm}$ subgingivalde olacak şekilde prepare edildi. Prepare edilen dişlerin aynı seansta geçici kron malzemesi (Dentalon Plus, lot number 010501, Heraeus-kulzer, Wehrheim, Almanya) ile geçici restorasyonları yapıldı ve geçici siman ile (Vision Provisory, lot number 965, ADD, İstanbul, Türkiye) simante edildi. Hastalara oral hijyen eğitimi verilip ikinci seans (ölçü seansı) için 7 gün sonraya randevu verildi. İkinci seansta ağrı ve hassasiyet şikâyeti olmayan, kanal tedavisi ihtiyacı duyulmayan bireylerle çalışmaya devam edilmiştir. Seans başlangıcında periodontal indeks ölçümleri Williams sondu ile yapılmıştır. İkinci seanstaki bu ölçümler başlangıç ölçümleri ' 0 ' olarak kabul edilmiş Hasta Takip Formuna kaydedilmiştir.

Çalışmada Kullanılan İndeksler ve Klinik

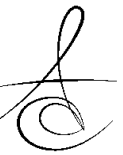




\section{Ölçümler}

Sondalama derinliği (PD): Dişeti oluğu tabanıyla, serbest dişeti kenarı arasındaki mesafedir. Williams sondu yardımıyla, milimetrik ölçülmüştür. Bireylerden sadece başlangıç ölçümleri alınmış olup, çalışmaya 3 $\mathrm{mm}^{\prime}$ den daha fazla sondalama derinliği bulunan dişleri olan bireyler dâhil edilmemiştir.

Gingival indeks (GI): Cep sondalamasında, enflamasyonun en önemli bulgusu olan kanama varlığı ve dişetinin enflamasyon derecesine bakılarak 0-3 arası yapılan değerlendirmedir. Aynı arktaki prepare edilen tüm dişlerin dört yüzeyinden alınan ölçümlerin ortalamasının toplamı / Diş sayısına bölümü ile hesaplanır. Tüm katılımcıların 0, 1, 7, 28. gün ölçümleri kaydedilmiştir. Sadece 0 ve 1 puanına sahip bireyler çalışmaya dahil edilmiştir.

Periodontal İndeks (PI): Bu indekste dişetinde enflamasyon varlığı, enflamasyon şiddeti, cep oluşumu 1-6 arasında değerlendirilir. Dişe ait skorlar toplanarak diş sayısına oranlanır ve kişinin periodontal indeks puanı hesaplanır. Tüm katılımcıların 0,1 , 7, 28. gün ölçümleri kaydedilmiştir.

Dişeti çekilmesi: Çalışmada preparasyonun bitim çizgisi ile serbest dişeti kenarı arasındaki mesafe dişlerin sadece bukkal yüzeyinden ölçüm yapılarak hesaplanmış olup puanlama her bireydeki çekilme görülen diş sayısı olarak kaydedilmiştir. Bireylerin 0, 1, 7, 28. gün ölçümleri kaydedilmiştir.

Hassasiyet: Değerlendirmede soğuk hava testi kullanılmıştır. Dişlerin bukkal kole bölgesine $20 \pm 3{ }^{\circ} \mathrm{C}$ sıcaklıkta 60-65 psi basınçta dental hava-su spreyi ile 1 saniye süresince hava sıkılarak ölçüm yapılmıştır. Puanlama bireylerde hassasiyet görülen diş sayısı olarak kaydedilmiştir. Bireylerin 0, 1, 7, 28. gün ölçümleri kaydedilmiştir.

Yöntem ve Uygulama: Çalışmada; konvansiyonal kord tekniği, kord ve alüminyum klorid $\left(\mathrm{AlCl}_{3}\right)$ solüsyonun birlikte uygulandığı mekanokimyasal teknik ve retraksiyon pastası olmak üzere 3 farklı retraksiyon yöntemi kullanılmıştır. Her bireye uygulanacak olan retraksiyon yöntemi rastgele olarak seçilmiştir. Ölçüye başlamadan önce bireylerin heyecan ve anksiyete durumunu değerlendirmek amacıyla Şekil 2 deki soru 1 (S1) ve soru 2 (S2) VAS üzerinde puanlanarak kaydedilmiştir.Grupların hepsinde retraksiyon öncesi ilgili bölgeye lokal anestezi uygulanmıştır. Her bireyde iki aşamalı putty-wash ölçü tekniği kullanılmıştır. Ölçülerin ilk aşaması PVS içerikli (Panasil, lot number
163681, Kettenbach, Eschenburg,Almanya) putty ölçü maddesi ile alındıktan sonra retraksiyon işlemine geçilmiştir.(Tablo 1)

Tablo1. Kullanılan retraksiyon yöntemlerinin marka ve üretici firma bilgileri

\begin{tabular}{|c|c|c|c|}
\hline \\
\hline \multicolumn{2}{|c|}{ Yöntemler } & Marka & $\begin{array}{l}\text { Üretici } \\
\text { Firma }\end{array}$ \\
\hline $\begin{array}{l}\text { GRUP } \\
1\end{array}$ & Kord (10 dk) & $\begin{array}{l}\text { Ultrapak@ } \\
\text { Lot:BB9B3 }\end{array}$ & $\begin{array}{c}\text { Ultradent } \\
\text { products, inc. }\end{array}$ \\
\hline $\begin{array}{l}\text { GRUP } \\
2\end{array}$ & $\begin{array}{l}\text { Kord + \%15 } \\
\mathrm{AlCl}_{3}(3-5 \mathrm{dk})\end{array}$ & $\begin{array}{l}\text { Racestyptine } \AA \\
\text { Lot:B13421AC }\end{array}$ & $\begin{array}{l}\text { Septodont } \\
\text { product co }\end{array}$ \\
\hline $\begin{array}{c}\text { GRUP } \\
3\end{array}$ & $\begin{array}{l}\text { Retraksiyon } \\
\text { pastası(2 dk) }\end{array}$ & $\begin{array}{c}\mathrm{MM}^{\mathrm{TM}} \mathrm{ESPE}^{\mathrm{TM}} \\
\text { Astringent } \\
\text { Retraction Paste } \\
\text { Lot: } 56944 \\
\end{array}$ & $\begin{array}{c}\text { 3M ESPE } \\
\text { Dental } \\
\text { Ürünler, } \\
\text { Almanya }\end{array}$ \\
\hline
\end{tabular}

Her grupta retraksiyon materyalleri uzaklaştırıldıktan sonra ölçülerin ikinci aşaması PVS içerikli (Panasil, Kettenbach, lot number 150561055, Eschenburg, Almanya) light body ölçü materyali ile alınmıştır. Ölçü işlemi tamamlandıktan sonra Şekil 2 deki sorular değerlendirilmiş ve puanlamaları tabloya kaydedilmiştir. Ölçü alma işlem süresi hesaplaması şu formüle göre hesaplanmıştır:

Retraksiyon yöntemini dişlere uygulama süresi + bekleme süresi + light body ile ölçü alma süresi.

Bireylerin rutin sabit protetik restorasyon yapım aşamaları devam ederken ölçü seansından sonraki 1 , 7, 28. günlerde bireylerin gingival indeks, periodontal indeks, dişeti çekilmesi ve hassasiyet puanlamaları ve hasta takip formunda hastaların rahatsızıklarına dair soruların VAS puanlamaları tablolara kaydedilmiştir. Metal prova seansında metallerin marjin uyumları ve tekrar ölçü ihtiyaçları uygulayıcı hekim tarafından görsel olarak değerlendirilmiş ve takip formuna kaydedilmiştir. Metal prova ve dentin prova seansları uygulandıktan sonra hastanın restorasyonları Çinko polikarboksilat siman (Adhesor carbofine, SpofaDental, Lot number 2480086-2, Prag, Çek cumhuriyeti ) ile simante edilmiştir.

Verilerin istatistiksel analizinde Windows için kullanılan SPSS 20 paket programı kullanılmıştır. Kategorik ölçümlerin gruplar arasında karşılaştırımasında Ki Kare test istatistiği kullanılmıştır. Sayısal ölçümlerin normal dağılım varsayımını sağlayıp sağlamadığı Kolmogrov Smirnov testi ile test edilmiştir. Varsayımların sağlanmaması durumunda ise Mann Whitney U testi, normal dağılım göstermeyen sayısal ölçümlerin ikiden fazla grup arasında genel karşılaştırmada Kruskal Wallis testi kullanılmıştır. Ancak, olası tüm çoklu karşılaştırmalarda Tip I hatayı kontrol edebilmek

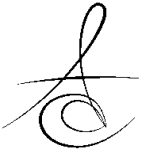


için Bonferroni düzeltmesi kullanılmıştır. Tüm testlerde istatistiksel önem düzeyi 0,05 olarak alınmıştır.

\section{HASTA TAKIP FORMU}

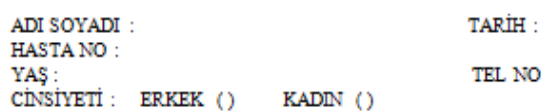

TEL NO :

EĠiTiM DURUMU : ILKOKUL () LISE () ÜNIVERSITE () Y.LISANS ()

Herhangi bir sistemik rahatsızlığını var mu? KALP HAST () DIABETES MELLiTUS() HIIPERTANSIYON () DIĞER( )

Kullandığınz bir ilaç varsa adın yanmız

Psikolojik tedavi gönüyor musunuz? EVET () HAYIR ()

Sigara kullanyor musunuz? $\quad$ EVET () HAYIR ()

Dişlerinizi firçallyor musunuz? $\quad$ EVET () HAYIR ()

EVET ise günde ; $1 \mathrm{KEZ}$ () 2VEYA DAHA FAZLA () DÜZENSiz ()

Çene elcleminde rahatsıllığıız var mı? EVET () HAYIR ()

DENTAL DURUM

SAĞ $\quad$ SOL Okluzal \begin{tabular}{lllllllll|llllllll} 
Ust & 18 & 17 & 16 & 15 & 14 & 13 & 12 & 11 & 21 & 22 & 23 & 24 & 25 & 26 & 27 & 28 \\
\hline
\end{tabular} \begin{tabular}{lllllllll|llllllll} 
Alt & 48 & 47 & 46 & 45 & 44 & 43 & 42 & 41 & 31 & 32 & 33 & 34 & 35 & 36 & 37 & 38
\end{tabular}

Eksik diģler:M Dolgulu diģler: $F$ Kronhu diģler: $K$

ADI SOYADI :

HASTANO:

Retraksiyon yöntemi: $\operatorname{Kord}(1)$ () Kord $+\mathrm{AlCl}$ (2) () Retraksiyon Pastasl (3) ()

$\begin{array}{lllllllllll}0 & 1 & 2 & 3 & 4 & 5 & 6 & 7 & 8 & 9 & 10\end{array}$

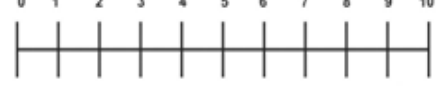

ÖLCCÜ SEANSI (0)

S1*: Şu anki heyecan durumuruzu skalada karş̧llk gelen bölümde içaretleyiniz ( 0 : Çok sakinim 10: Çokhuzursuzum)

S2*: Hekimin hastanun anksiyete durumumu VAS skalasında de ǧerlendime skoru.

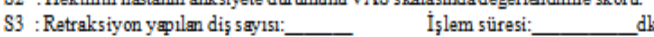

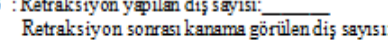

$\mathrm{S4}^{*}$ : Yöntemin diş̧tini lateral yönde yerdešiştirme etkinliǧini hekimin VAS skalasında değerlendirme skoru.

$\mathrm{S}^{*}$ : Uygulanan işlemin sizin içinne kadar rahatsız edici olduğumu skalada gö steriniz. (0: Çok rahat 10 : Çok rahatsız)

S6*: Işlem sırasında duyduğunuz ağrıy skalada karş̧llk gelen bölümde gösteriniz.

(0: Ağrr olmaması 10: Şiddetli ağr

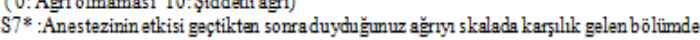

gösteriniz. (0: Ağ̣̆ olmamas1 10: Șiddetli ağri)

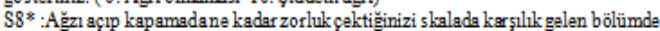
gösteriniz. (0: Hiç zorluk çekmiyonm 10: Çok zorluk çekiyormm)

ÖLCÜDEN SONRAKİ $1 ., 7.28$. GÜNLER $(1,7,28)$

S7*: Tedavi uygulanan dişlerde hissettiğniziz ağryy skaladakarşlilk gelen bölüm de gö steriniz (0:Ağrılmamas1 10: Șiddetli ağr 1 )

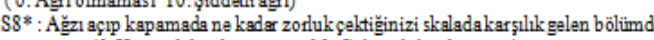

gösteriniz. (0: Hiç zorluk çekmiyorm 10: Çok zorluk çekiyorum)

S9*: Sicak ve soğukyiyip içme sıras inda duyduğunuzağrnyı skalada karş̧ll gelen bölümde

gösteriniz. (0: Ağ̣̆ olmaması 10: Șiddetli ağrn)

$\$ 10^{*}$ : Dişleri firçalama sırasunda nekadar zorlandığııızı skaladakarşlllk gelen bölümde

gösteriniz. (0: Hiç zorluk çekmiyonm 10: Çok zorluk çekiyorum)

S11 : Ağrn kesici kullanma ihtiyacı hissettiniz mi? EVET () HAYIR()

METAL PROVA SEANST

S12: Metallerin marjin uvumu: IYI () KOTU()

S13 : Tekrar ölçü ihtiyacı duyuldu mu? EVET () HAYIR()

S14 : Duyulduys sa kaç kere tekrar edildi
ADI SOYADI
HASTA NO:

PERIODONTAL INDEKSLER

\begin{tabular}{|l|l|l|l|l|l|l|l|}
\hline & $\mathrm{PD}(\mathrm{mm})$ & GI & PI & $\mathrm{KAR}(\mathrm{mm})$ & $\begin{array}{c}\mathrm{Kanama} \\
(+/)\end{array}$ & $\begin{array}{c}\text { Hassasiyat } \\
(+-)\end{array}$ & $\begin{array}{c}\text { Mobilite } \\
(+-)\end{array}$ \\
\hline 0 & & & & & & & \\
\hline 1 & & & & & & & \\
\hline 7 & & & & & & & \\
\hline $\mathbf{2 8}$ & & & & & & & \\
\hline
\end{tabular}

VAS SKORLARI

\begin{tabular}{|l|l|l|l|l|l|l|l|l|l|}
\hline & $\mathrm{S} 1$ & $\mathrm{~S} 2$ & $\mathrm{S4}$ & $\mathrm{S} 5$ & $\mathrm{S6}$ & $\mathrm{S} 7^{*}$ & $\mathrm{~S} 8^{*}$ & $\mathrm{S9*}$ & $\mathrm{S10^{* }}$ \\
\hline 0 & & & & & & & & & \\
\hline 1 & - & - & - & - & - & & & & \\
\hline 7 & - & - & - & - & - & & & & \\
\hline 28 & - & - & - & - & - & & & & \\
\hline
\end{tabular}

Şekil 1. Hasta takip formu-1-3

\section{BULGULAR}

Çalışmaya dâhil edilen dişlerin ark içerisindeki konumlarının gruplara göre dağılımı Tablo 2 de verilmiştir. Dişlerin bölgelere göre dağılımı açısından gruplar arasında istatistiksel açıdan fark bulunmamıştır.

Tablo 3 te Retraksiyon sırasında ölçülenVAS skorlarının verilmiştir.

Şekil 2 de sırası ile retraksiyon sırasında görülen ağrının(S7), retraksiyon sonrası gelişen hassasiyetin (S9)ve retraksiyon sonrası hastanın diş fırçalama sıra- sındaki ağrısının(S10) zamana bağlı değişimin veril- mektedir. Yedinci ve 28. Günde gruplar arasındaki farklılık kaybolmuştur $\left(p_{\text {grup }}=0.594\right.$, $\mathrm{p}_{\text {grup }}=0.369$ )Her 3 grubunda skorlarında zaman içinde azalma görül- mektedir. Grupların zamana bağlı gösterdiği değişim gruplar arasında istatistiksel olarak anlamlı farklılık göstermiştir ( $\left.p_{\text {grupxzaman }}=0.020\right)$.

Tablo2: Diş bölgelerinin gruplara göre dağıımı

\begin{tabular}{|c|c|c|c|c|}
\hline & $\begin{array}{c}\text { Kord } \\
\text { Sayı } \\
(\%)\end{array}$ & $\begin{array}{c}\text { Kord+AICl3 } \\
\text { Sayı (\%) }\end{array}$ & $\begin{array}{c}\text { Retraksiyon } \\
\text { pastası } \\
\text { Sayı (\%) }\end{array}$ & P \\
\cline { 1 - 4 } Kesici & $\begin{array}{c}53 \\
(31.4)\end{array}$ & $72(40.7)$ & $49(27.2)$ & \\
\cline { 1 - 4 } Küçükazı & $\begin{array}{c}56 \\
(33.1)\end{array}$ & $53(29.9)$ & $74(41.1)$ & \multirow{2}{*}{0.052} \\
\cline { 1 - 4 } Büyükazı & $\begin{array}{c}60 \\
(35.5)\end{array}$ & $52(29.4)$ & $57(31.7)$ & \\
\hline
\end{tabular}


Tablo 3.

\begin{tabular}{|c|c|c|c|c|}
\hline & $\begin{array}{c}\text { Kord } \\
X \pm S d\end{array}$ & $\begin{array}{c}\text { Kord }+\mathrm{AlCl}_{3} \\
\mathrm{X} \pm \mathrm{Sd}\end{array}$ & $\begin{array}{c}\text { Ret.Pastası } \\
\mathrm{X} \pm \mathrm{Sd}\end{array}$ & $\mathbf{P}$ \\
\hline $\begin{array}{l}\text { Anksiyete(hasta } \\
\text { beyanı) }\end{array}$ & $\begin{array}{c}6 \pm 1 \\
6(3-10)\end{array}$ & $\begin{array}{l}5.8 \pm 1.7 \\
5(2-9)\end{array}$ & $\begin{array}{c}5.8 \pm 1.6 \\
6(2-9)\end{array}$ & 0.883 \\
\hline $\begin{array}{l}\text { Anksiyete (hekim } \\
\text { gözlemi) }\end{array}$ & \begin{tabular}{|l|}
$6.5 \pm 1.5$ \\
$6(4-10)$ \\
\end{tabular} & $\begin{array}{l}6.1 \pm 2 \\
6(0-10) \\
\end{array}$ & $\begin{array}{c}5.9 \pm 1.8 \\
6(0-10) \\
\end{array}$ & 0.495 \\
\hline $\begin{array}{l}\text { Retraksiyon } \\
\text { miktarı }\end{array}$ & $\begin{array}{c}6.2 \pm 1.3^{*} \\
6(3-9) \\
\end{array}$ & $\begin{array}{c}7.1 \pm 1.2 * \Delta \\
7(4-9)\end{array}$ & $\begin{array}{l}6.2 \pm 1.5 \Delta \\
6.5(3-9) \\
\end{array}$ & 0.002 \\
\hline $\begin{array}{l}\text { Uygulanan } \\
\text { yöntemin } \\
\text { hastaya verdiği } \\
\text { rahatsızlık(Hast } \\
\text { a beyanı) }\end{array}$ & $\begin{array}{c}5.7 \pm 1.8^{*} \\
5(2-9)\end{array}$ & $\begin{array}{l}5.2 \pm 2.2 \\
\Delta 5(0-10)\end{array}$ & $\begin{array}{c}3.2 \pm 1.8^{*} \Delta \\
3(0-8)\end{array}$ & 0.0 \\
\hline Ağrı hissi & $\begin{array}{c}2.6 \pm 2.1^{*} \\
3(0-7)\end{array}$ & $\begin{array}{l}2.1 \pm 2 \Delta \\
2(0-8)\end{array}$ & $\begin{array}{c}1 \pm 1.5 * \Delta \\
0(0-4)\end{array}$ & 0.002 \\
\hline $\begin{array}{l}\text { Retr } \\
\text { sonr }\end{array}$ & $\begin{array}{c}5.4 \pm 1.3^{*} \\
5(3-9)\end{array}$ & $\begin{array}{c}4.9 \pm 1.1 \Delta \\
5(3-8)\end{array}$ & \begin{tabular}{|}
$3.1 \pm 1.2 * \Delta$ \\
$3(0-5)$
\end{tabular} & k0.001 \\
\hline $\begin{array}{l}\text { Ağız açıp } \\
\text { kapamada ağrı } \\
\text { ve kısıtlama }\end{array}$ & $\begin{array}{l}1.3 \pm 2^{*} \\
0(0-6)\end{array}$ & $\begin{array}{c}1.1 \pm 2.2 \Delta \\
0(0-8)\end{array}$ & $\begin{array}{c}0.1 \pm 0.8^{*} \Delta \\
0(0-5)\end{array}$ & 0.007 \\
\hline
\end{tabular}
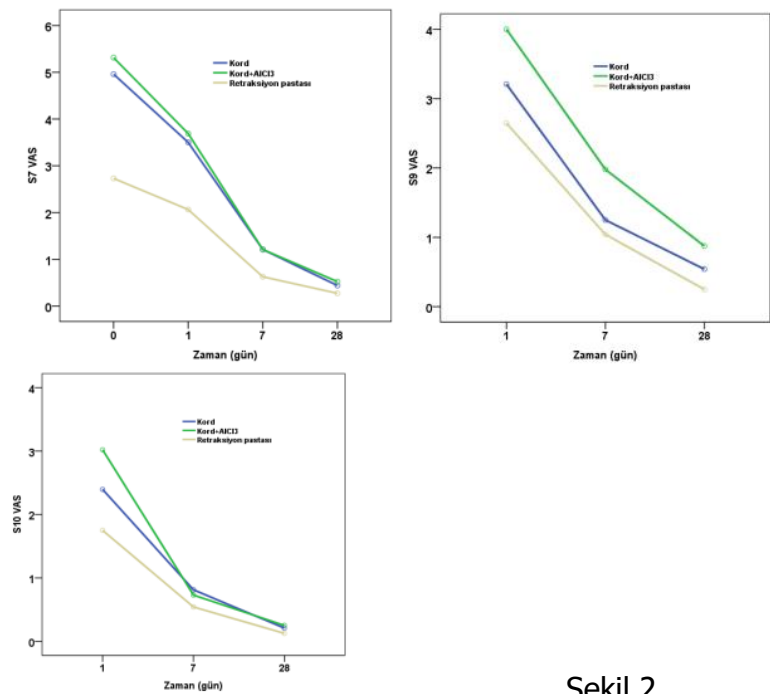

Şekil 2.

Tablo 4 te retraksiyon sonrası ağrı kesici kullanma ihtiyacı, ölçü netliği ve marjin uyumlarının istatistiği verilmektedir.

Ölçü seansında retraksiyon işlemi sonrası ağzı açıp kapamadaki zorluk açısından gruplar arasındaki fark istatistiksel olarak anlamlı bulunmuştur $(p=0,002)$ 1.gün skorlarında 1 . grubun $\% 93,8^{\prime}$ inin, 2. grubun $\% 97,9^{\prime}$ unun, 3. grubun $\% 100^{\prime}$ ünün ağzı açıp kapa- mada hiç şikayeti olmamıştır ve gruplar arası fark anlamlı değildir $(p=0,374)$. 7. günden itibaren hepsinin skoru aynıdır ve gruplar arası fark anlamlı değildir $(p=0,331)$. Tablo 5 te Periodontal indeks, gingival indeks, dişeti çekilmesi ve hassasiyet bulgularının istatistiksel analizi verilmektedir.

Tablo 4

\begin{tabular}{|c|c|c|c|c|}
\hline & $\begin{array}{l}\text { Kord } \\
\text { Sayı } \\
(\%)\end{array}$ & $\begin{array}{l}\text { Kord+AICI } \\
\mathbf{3} \\
\text { Sayı (\%) }\end{array}$ & $\begin{array}{l}\text { Retraksiy } \\
\text { on } \\
\text { pastası } \\
\text { Sayı (\%) }\end{array}$ & $\mathbf{p}$ \\
\hline $\begin{array}{l}\text { S11 } \\
\text { Ağrı kesici } \\
\text { kullanma } \\
\text { intiyacı } \\
\text { EVET ( x) } \\
\text { HAYIR () }\end{array}$ & $25(52.1)^{*}$ & $26(54.2) \Delta$ & $9(18.8) * \Delta$ & $<0.001$ \\
\hline $\begin{array}{l}\text { S12 } \\
\text { Metallerin } \\
\text { marjin } \\
\text { uyumu } \\
\text { IYYİ }(x) \\
\text { KÖTÜ }()\end{array}$ & $38(79.2)$ & $44(91.7)$ & $41(85.4)$ & 0.213 \\
\hline $\begin{array}{l}\text { S13 } \\
\text { Ölçü } \\
\text { tekrarı } \\
\text { ihtiyacı } \\
\text { EVET (x) } \\
\text { HAYIR ( ) }\end{array}$ & $10(20.8)$ & $4(8.3)$ & $7(14.5)$ & 0.213 \\
\hline
\end{tabular}

$\Delta^{\prime}$ ve ${ }^{\prime * \prime}$ simgeleri gruplar arasındaki farklılığı temsil etmektedir

Hassasiyet açısından grupların zamana bağlı gösterdiği değişim istatistiksel olarak anlamlıdır $(p<0.001)$. 1. Günde gruplar arasındaki farklılık anlamlıdır. Kord+AICl3 grubunda hassasiyet görülen diş sayısı diğer gruplara göre daha fazladır. 7. Günde Kord+AlCl3 ve retraksiyon pastası grupları arasında farklılık bulunmuştur. 28. Günde gruplar arası farklılık ortadan kalkmıştır. Dişeti çekilmesi açısından grupların zamana bağlı gösterdiği değişim istatistiksel olarak anlamlıdır $(p<0.001) .1,7,28$. Günlerde retraksiyon pastası grubu diğer 2 gruptan farklı bulunmuştur. Gruplardaki zamana göre değişim gruplar arasında farklılık göstermemiştir $(p=0.702)$. 
Tabo 5.

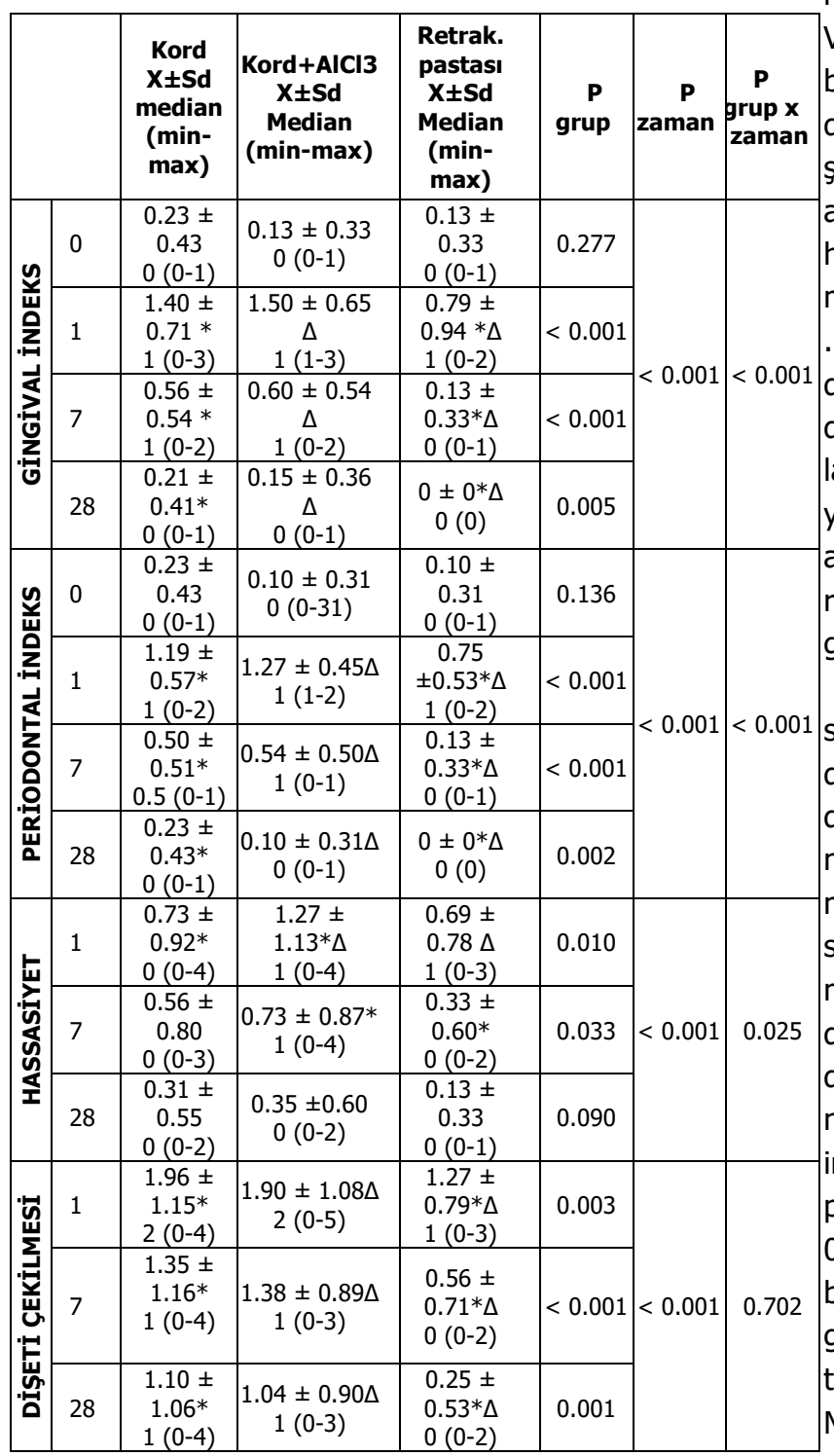

\section{TARTIŞMA}

Dişeti oluğu retraksiyon yöntemleri yıllardır birçok araştırmaya konu olmuştur. Ancak Literatürde retraksiyon yöntemlerinin hasta konforunu değerlendirme kriterleri ile ilgili bir fikir birliği yoktur. Önceki çalışmalar retraksiyon sırasındaki ağrıyı, kötü tat hissini, işlem süresini ve retraksiyon sonrası hassasiyeti, dişetindeki değişimleri konfor açısından değerlendirmişlerdir $^{9-13}$. Mevcut çalışmada bu yapılan değerlendirmelere ek olarak katılımcıların postoperatif dönemde ağız açıp kapamadaki kısıtılığı, sıcak-soğuk yeme içmedeki ve diş fırçalamadaki zorluğu, ağrı kesici kullanma ihtiyacı ve işlem sırasında duydukları rahatsızlık hisleri VAS kullanılarak değerlendirilmiştir. VAS ağrı değerlendirme ölçeği olarak sıklıkla kullanılan bir yöntemdir. Görsel analog ölçekler ve sayısal değerlendirme ölçekleri ağrı yoğunluğunu yansıtacak şekilde sayısal bir ifade ile kullanılmaktadır. Sınırı bir aralık olması hastaların karar verme sürecini hızlandırabilir. Ancak pratikte, 0-10 şeklindeki puanlama en yaygın olarak kabul gören puanlama şeklidir ${ }^{14}$ .Bireylerin yaş, cinsiyet, eğitim düzeyleri, psikolojik durumları ve medikal hikâyeleri preoperatif anksiyete durumlarını etkileyebilir. Mevcut çalışmada, katılımcıların sosyodemografik özellikleri ve preoperatif anksiyete durumları açısından gruplar arasında istatistiksel açıdan farklılık görülmemiştir. Bu da tüm gruplar için retraksiyon işlemine eşit koşul- larda başlanıldığını göstermektedir.

Sabit bir restorasyon yaparken ölçü aşamasındaki kritik faktörlerden biri marjinal dişeti dokusunda enflamasyon olmamasıdır. Ölçü seansında dişeti dokusunun sağlıklı ve servikal marjinin doğru konumunda olması dişeti retraksiyonunun basit ve atravmatik bir işlem olmasını sağlamaktadır ${ }^{15}$. Preparasyon sırasında oluşturulan mekanik travma dişetindeki inflamatuar cevabı indüklemektedir. İnflamasyonlu dişetinde kanama olur, retraksiyon zorlaşır, agresif bir prosedür uygulanabilir ve bu dişetinde çekilme ile sonuçlanabilir. Servikal marjinin çok derin olması da dişeti inflamasyonuna neden olmaktadır. Marjinin optimum pozisyonu sağlıklı serbest dişeti kenarından en fazla $0,5 \mathrm{~mm}$ uzakta olmalıdır ${ }^{11}$. Ayrıca marjin uyumları iyi, biyouyumlu bir malzemeden yapılmış, hastanın bölgede hijyen sağlayabileceği bir geçici restorasyon dişeti dokularının daha çabuk iyileşmesini sağlayacaktır. Mevcut çalışmada, katılımcılara marjin uyumları iyi geçici restorasyonlar uygulanmış ve oral hijyen eğitimi verilerek ölçü için preparasyon sonrası 7 gün beklenilmiştir. İlk dişeti indeksi ölçümleri de bu seansta yapılarak kriterlere uyan bireyler çalışmaya dâhil edilmiştir.

Yeterli yer değiştirme sağlayabilmek ve ölçü maddesinin sulkus bölgesinden yırtılmadan ve distorsiyona uğramadan uzaklaşması için yeterli çapta bir retraksiyon kordu kullanılmalıdır ${ }^{16}$. Dişeti oluğu genişliği sond ya da periodontal sond ile ölçülüp kord seçimi yapılabilir. Mümkün olan en büyük kordun dişeti oluğuna atravmatik şekilde yerleştirilmesi gerekmektedir ${ }^{11}$. Olması gerekenden daha küçük çapta kord seçimi minimal travmaya neden olur; ancak dişeti oluğunda yeterli bir genişleme sağlayamaz. Başarılı bir ölçü için

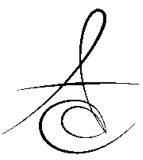


retraksiyon sonrası sulkular genişliğin minimum 0,2 $\mathrm{mm}$ olması gerekmektedir ${ }^{4}$. Çok büyük kord seçimi ise travmatik uygulamaya, dişeti epitelinde hasara, işlem sırasında kanamaya ve sonuçta dişetinde çekilmeye neden olabilir. Mevcut çalışmaya 18-65 yaş arası geniş bir yaş aralığındaki bireyler dâhil edilmiş, maksillar ve mandibular diş, yaş, cinsiyet ayrımı gözetilmemiştir. Bu durum da araştırmacıyı dişeti kalınlıklarına ve dişeti oluğu genişliklerine göre farklı çapta retraksiyon kordu seçimine yöneltmiştir. Çalışmada en sık kullanılan Ultrapak® retraksiyon kordu \#1 numara olmuştur.

Retraksiyon kordunun kimyasal ajanı absorbe etme yeteneği ipin uzunluğu, kalınlığı, yapısı, nemlenebilme özelliği kadar kimyasal solüsyon içerisinde ıslatılma süresine de bağlıdır. Mevcut çalışmada, Kord+ $\mathrm{AlCl}_{3}$ grubunda kordlar dişeti oluğuna kuru olarak yerleştirilmiş, yerleştirildikten hemen sonra üretici talimatına uygun olarak oluk içerisindeyken pipet yardımıyla kordlara 1-2 damla solüsyon emdirilmiştir. Böylece hızı bir uygulama ile kimyasal ajanın dişlerle temas süresi retraksiyon yapılan tüm dişler için hemen hemen eşitlenmiştir. Çalışmalar, retraksiyon ipindeki kimyasal ajan miktarı arttıkça daha etkin bir hemoroji ve retraksiyon sağlandığını göstermektedir ${ }^{17,18}$. Ayrıca retraksiyon ipinin 20 dakika kimyasal ajan içerisinde bekletilmesinin yeterli medikasyon sağladığı rapor edilmiştir ${ }^{19}$. Ancak retrakte edilecek diş sayısının fazla olduğu durumlarda ilk retrakte edilen diş ile son retrakte edilen diş arasında süre açısından geniş bir fark olmaktadır. $\mathrm{Bu}$ uygulama ile tüm ağız restorasyonlarında ilk retrakte edilen dişler tehlikeli sürelere ulaşabilir. Retraksiyon sürecinin artması daha fazla kimyasalın epitele geçmesine ve dişetinde geri dönüşü olmayan hasarlara neden olabilmektedir ${ }^{20}$. Çalışmamızda pipet yardımıyla yapılan hızı uygulama ile ilk retrakte edilen dişin süre dezavantajı ortadan kaldırılmıştır.

Retraksiyon kordunun veya pastasının dişeti sulkusunda bekleme süresi kullanılan retraksiyon ajanının çeşidine ve konsantrasyonuna göre farklılık göstermektedir. Mevcut çalışmada, her bir teknik için üretici firma tarafından önerilen uygulama süreleri dikkate alınmıştır. Konvansiyonel kord grubu en uzun uygulama süresine sahip gruptur (8-10 dk). Kuru retraksiyon kordunun sulkus içerisinde 8-10 dk bekletilmesi gerektiği literatür tarafından desteklenmektedir $^{1,11}$. Retraksiyon kordlarının $10 \mathrm{dk}^{\prime}$ dan fazla sulkus içerisinde kalmasının ise nekroza sebep olduğu rapor edilmiştir ${ }^{9,20}$. Mevcut çalışmada, Kord $+\% 15$ $\mathrm{AlCl}_{3}$ grubunda kordun lateral genişletme için, solüs- yonun da hemostaz ve oluk sıvısı kontrolü için yeterli süreye ihtiyacı vardır. 3-5 dakika sürenin hem genişletme hem de hemostaz için yeterli olduğu sonuçlara bakılarak söylenebilir. Retraksiyon ve dolayısıyla ölçü süresinin az olması hasta konforu ve memnuniyetini arttıran bir faktördür. Uygulama süresinin 2 dakika olduğu retraksiyon pastası grubunda bireyler diğer gruplara göre işlemden daha az rahatsızlık duymuşlardır (S5 skoru). İşlem süresinin uzun olması aynı zamanda ağzın uzun süre açık kalmasına ve eklem ağrılarına neden olabilmektedir. 1. gün puanlamalarında ağız açıp kapamada zorluk çeken katılımcı yüzdesinin en fazla Kord grubunda görülmesi sürenin konfor üzerine etkisini açıklamaktadır. Özellikle eklem problemi olan bireylerde hızı ve pratik yöntemler kullanılması hasta konforunu arttırmaktadır.

Klinik etkinliği ölçmek, belirlenmiş etkin bir ölçüm aleti olmadığı için uygulayıcılar için halen bir ikilemdir. Mevcut çalışmada, yöntemlerin klinik performansını değerlendirmek için horizontal yönde yer değiştirme etkinliği, retraksiyon sonrası kanama görülen diş sayısı ve toplam ölçü süreleri esas alınmıştır. Yöntemin sulkustaki yer değiştirme etkinliği, araştırmacı tarafından kord ya da pasta sulkustan uzaklaştırıldıktan sonra kolay görülebilir ve ulaşılabilir olduğu için dişlerin bukkal yüzeylerinden subjektif olarak VAS kullanılarak değerlendirilmiştir ${ }^{21,22}$.

Dişeti oluğu sıvısı ve kanama kontrol edilerek kuru bir ortam oluşturulması ölçünün kalitesini etkilemektedir ${ }^{23,24}$. Retraksiyon ipleri, dişeti oluklarından çıkartılırken dokulara yapışıp epitele zarar verebilir ve kanamaya sebep olabilir. Bu sebeple çalışmada kordlar çıkartılmadan nemlendirilmiş ve çıkartıldıktan hemen sonra da solüsyon artıklarını ve varsa kanamayı uzaklaştırmak amacıyla uygulama bölgeleri 10 sn hava su spreyi ile yıkanmış ve kurutulmuştur. Mevcut çalışmada, retraksiyon sonrası kanamanın en fazla geleneksel kord grubunda gözlenmesi önceki çalışmaları desteklemektedir ${ }^{21,25}$. Araştırmacılar; kanamasIz, kuru bir sulkus elde edebilmek için mekanik ve kimyasal yöntemin kombine edilmesi gerektiğini vurgulamışlardır ${ }^{3,8}$. Mevcut çalışmada, \%15' lik hemostatik ajan $\left(\mathrm{AlCl}_{3}\right)$ içeren iki grupta da kanama daha az görülmüştür. Kord kullanılan gruplarda kord kalınlığı araştırmacı tarafından dişeti kalınlığı ve sulkus genişliği kontrol edilerek seçilmiştir; ancak retraksiyon pastası direkt sulkusa sıkılarak kullanıldığından kalınlığı kontrol etmek mümkün olmamıştır. Retraksiyon pastasının içeriğindeki kaolin su emerek şişmekte ve mekanik

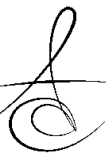


retraksiyon sağlamaktadır. Kaolinin emdiği su miktarı ve sulkus genişliği her hastada farklılık gösterebileceğinden daha dar sulkuslarda çok genişleyip travma ve kanamaya sebep olmuş olabilir. Kanama kadar dişeti oluğu sıvısını da kontrol altına almak retraksiyon açısından önemlidir. Wöstmann ve ark, ${ }^{26}$ konvansi- yonel kord, epinefrin emdirilmiş kord ve kordsuz (Expasyl) tekniği karşılaştrdıkları çalışmada, retraksiyon öncesi ve sonrası dişeti oluğu sıvısı miktarını ölçmüşler, kuru kordun oluk sıvısını arttırdığını, diğer grupların ise azalttığını tespit etmişlerdir. Retraksiyon sonrası kanama görülen diş sayısı ve ölçü tekrarının en fazla geleneksel kord grubunda görülmesi nem ve ölçü kalitesi ilişkisini açıklamaktadır.

Retraksiyon işlemi sırasında ve sonrasında duyulan ağrı hasta konforunu önemli ölçüde etkilemektedir. Mevcut çalışmada, tüm gruplarda retraksiyon işlemi anestezi altında yapılmış olmasına rağmen işlem sırasında duyulan ağrı ve rahatsızlık hissi değerlendirildiğinde geleneksel kord tekniği ve retraksiyon pastası arasında farklılık bulunmuştur. Kordun dişeti içerisine yerleştirilmesi sırasında oluşan basınç hissi bireyler tarafından ağrı olarak algılanmış olabilir. Anestezinin etkisi geçtikten sonra yapılan değerlendirmede retraksiyon pastası daha az ağrılı ve daha konforlu bulunmuştur.

Postoperatif hassasiyet hasta konforunu olumsuz yönde etkileyen diğer önemli bir faktördür. Koledeki hassasiyet; kısa, keskin yükselen ağrılı ve ekspoze dentine uygulanan soğuk, sıcak ve kimyasal uyarılarla ortaya çıkan bir durumdur. Mekanik ya da mekanokimyasal retraksiyon işlemleri postoperatif hassasiyete neden olabilir. Dişeti retraksiyonu ajanları 1-3 arasında değişen $\mathrm{pH}$ değerlerine sahiptirler. Bu yüksek asidite bölgedeki smear tabakasının uzaklaş- masına ve servikal kısımdaki dentin tübüllerinin açığa çıkmasına neden olarak dentin hipersensivitesine neden olabilir ${ }^{27}$.

Çalışmada postoperatif gingival ve periodontal hastalığın derecesini ölçmek, oluşan gingivitise bağlı inflamasyonu, periodontitise bağlı bağ doku yıkımını analiz etmek için klinik tanı göstergeleri olan PD, GI, PI kullanılmıştır. Bu indeksler uygulaması kolay ve nispeten non-invazivdir. Birinci günde tüm gruplarda GI ve PI değerlerinde belirgin bir artış görülmüştür. Bu durum mekanik ve kimyasal travmaya bağlı oluşan inflamatuar hücre reaksiyonundan kaynaklanabilir ${ }^{9}$. Retraksiyon pastasının GI ve PI değerleri 1, 7, 28. günlerde en az seviyededir ve istatistiksel olarak diğer gruplardan farklı bulunmuştur. Diğer gruplar arasında fark bulunmamıştır. 7.günden sonra tüm gruplarda iyileşme gözlenmiştir. Diş firçalamada zorluk ve hassasiyet yaşayan hastalar oral hijyenlerini tam anlamıyla sağlayamadıklarından GI ve PI değişimleri de bu durumdan etkilenmiş olabilir. 7.günden itibaren gruplardaki hassasiyet görülen diş sayısının azalması bireylerin diş fırçalamadaki zorlanmalarını azaltmış ve indekslerini olumlu etkilemiştir. Yapılan histolojik çalışmalar, farklı solüsyonlarla birlikte kullanılan retraksiyon kordlarının farklı derecelerde gingival inflamasyona neden olduğunu ve dişetinin 3-24 gün arasında normal histolojik görünümüne döndüğünü göstermişlerdir ${ }^{2,5,28}$.

Retraksiyon ajanları dişeti oluğu içerisinde ince tek sıralı epitel hücreleri ve epitelyal ataşman ile direkt temasta olmakta ve böylece kimyasal ajanlar bağ dokusunu direkt etkilemiş olmaktadır ${ }^{2,8,9}$. Dişeti dokusunda meydana gelen tahribatın nedeni kimyasalların 1 ila 3 arasında değişen düşük pH seviyeleri olarak gösterilmektedir ${ }^{8}$. $\mathrm{AlCl}_{3}$, orta dereceli konsantrasyonlarda irritan gibi davranmakta, yüksek konsantrasyonlarda kostik etki yaratmaktadır ${ }^{3,8}$. Mevcut çalışmada kulanılan \%25 $\mathrm{AlCl}_{3}$ içeren solüsyon konsantrasyonu \%15 olacak şekilde dilue edilmiş ve retraksiyon pastasının $\% 15 \mathrm{AlCl}_{3}$ içeriği ile eşitlenmiştir. Klinik uygulamalarda, oluk sıvısı ve tükürük kimyasal ajanın konsantrasyonunu azaltır, böylece yıkıcı etkisini de azaltmış olur. Ayrıca, sağlıklı bir epitelin koruma görevi vardır. Kimyasal solüsyonların yıkıcı etkisi bariyer görevi görecek olan epitel tarafından azaltılmaktadır ${ }^{29}$.

\section{SONUÇ}

Sonuç olarak, mevcut çalışmanın sonuçları retraksiyon yöntemleri ve hasta konforu arasında anlamlı bir ilişki olduğunu ortaya koymaktadır. Kord ve $\mathrm{AlCl}_{3^{\prime}}$ in birlikte kullanıldığı mekanokimyasal yöntemin etkili bir hemostaz ve retraksiyon sağladığı, ancak hasta konforu açısından tartışmalı olduğu görülmüştür. Bu yönteme alternatif olarak ortaya çıkan retraksiyon pastasına karşı bireylerin toleransının ve konforunun diğer gruplara göre daha iyi olduğu gözlenmiş ve çalışmanın hipotezi reddedilmiştir.

\section{KAYNAKLAR}

1. Shillingburg HT. Fundamental of Fixed Prosthodontics. 3 ed Quintessence Publishing Co. London, 1997: 257-77.

2. Azzi R, Tsao TF, Carranza FA Jr, Kenney EB. Comparative study of gingival retraction methods. J Prosthet Dent 1983; 50: 561-5.

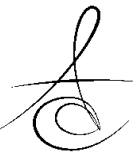


3. DonovanTE, Gandara BK, Nemetz H. Review and survey of medicaments used with gingival retraction cords. J Prosthet Dent 1985; 53: 525-31.

4. Laufer BZ, Baharav H, Cardash HS. The linear accuracy of impressions and stone dies as affected by the thickness of the impression magrin. Int J Prosthodont 1994; 7: 247-52.

5. Hansen PA, Tira DE, Barlo J. Current methods of finish-line exposure by practising prosthodontists. J Prosthodont 1999; 8: 163-170.

6. Bennani V, Schwass D, Chandler N. Gingival retraction techniques for implants versus teeth: Current status. J Am Dent Assoc 2008;139: 135463.

7. Lesage P. Expasyl: protocol for use with fixed prosthodontics. Dental News 2004; 11: 33-7.

8. Ekren O, Kurtoğlu C. Dişeti Retraksiyon Yöntemleri. Atatürk Ünv. Diş Hek. Fak. Derg. 2008; 2: 78-84.

9. Al Hamad KQ, Azar WZ, Alwaeli HA, Said KN. A clinical study on the effects of cordless and conventional retraction techniques on the gingival and periodontal health. J Clin Periodontol 2008; 35: 1053-8.

10. Yang JC, Tsai CM, Chen MS, Wei JY, Lee SY, Lin CT. Clinical study of a newly developed injectiontype gingival retraction material. Chin Dent J 2005; 24,3: 147-51.

11. Donovan TE, Chee W.L.Current concepts in gingival displacement. Dent Clin N Am 2004; 48: 433-4

12. Nemetz $H$, Donovan $T$, Landesman $H$. Exposing the gingival margin: a systematic approach for the control of hemorrhage. J Prosthet Dent 1984; 51: 647-51.

13. Weir DJ, Williams BH. Clinical effectiveness of mechanical-chemical tissue displacement methods. J Prosthet Dent 1984; 51: 326-9.

14. Waldman SD. Girişimsel Ağrı Tedavisi. Lüleli N (Çev), 2. basım. Philedelphia: Elsevier Science; 2001.

15. Beier US, Kranewitter R, Dumfahrt H. Quality of impressions after use of the Magic Foam Cord gingival retraction systemda clinical study of 269 abutment teeth. Int J Prosthodont 2009; 22: 143-7

16. Wöstmann B, Rehmann $P$, Balkenhol M. Influence of different retraction techniques on crevicular fluid flow. Int J Prosthodont. 2008; 21: 215-6.

17. Runyan DA, Reddy TG, Shimoda ML. Fluid absorbency of retraction cords after soaking in aluminum chloride solution. J Prosthet Dent 1988; 60: 676-8.

18. Cloyd S, Puri S.Using the double-cord packing technique of tissue retraction for making crown impressions. Dent Today 1999; 18: 54-9.

19. Csempesz F, Vag J, Fazekas A. In vitro kinetic study of absorbency of retraction cords. J Prosthet Dent 2003; 89: 45-9.

20. Löe $H$, Silness J. Tissue reactions to string packs used in fixed restorations. J Prosthet Dent 1963;13: 318-23.

21. Acar Ö, Erkut S, Özçelik TB, Ozdemır E, Akçil M. A clinical comparison of cordless and conventional displacement systems regarding clinical performance and impression quality. J Prosthet Dent 2014; 111: 388-94.

22. Kazemi M, Memarian M, Loran V. Comparing the Effectiveness of Two Gingival Retraction Procedures on Gingival Recession and Tissue Displacement: Clinical Study. Res. J Biol. Sci. 2009; 4: 335-9.

23. Rupp F, Axmann D, Geis-Gerstorfer J. Effect of relative humidity on the hydrophilicity of unset elastomeric impression materials. Int J Prosthodont 2008; 21: 69-71.

24. Nemetz $H$, Donovan $T$, Landesman $H$. Exposing the gingival margin: a systematic approach for the control of hemorrhage. J Prosthet Dent 1984; 51: 647-51

25. Weir DJ, Williams BH. Clinical effectiveness of mechanical-chemical tissue displacement methods. J Prosthet Dent 1984; 51: 326-9.

26. Wöstmann $B$, Rehmann $P$, Balkenhol M. Influence of different retraction techniques on crevicular fluid flow. Int J Prosthodont. 2008; 21: 215-6.

27. Gupta G, Kumar S, Rao H, Garg P, Kumar R, Sharma A, Sachdeva $H$. Astringents in dentistry: A review. Asian j. Pharm. Hea. Sci.2012; 2: 428-32.

28. Kopac I, Batista U, Cvetko E, Marion L. Viability of Fibroblasts in Cell Culture After Treatment with Different Chemical Retraction Agents. J Oral Rehabil. 2002; 29: 98-104.

29. Kopac I, M, Marion L. Electron microscopic analysis of the effect of chemical retraction agents on cultured rat keratinocytes. Prosthet Dent.2002 87: 51-6.

\section{Yazışma Adresi}

Yrd.Doç.Dr.Orhun EKREN

Çukurova Üniversitesi Diş Hekimliği

Fakültesi Protetik Diş Ted. A.D Balcalı

Sarıçam/Adana

Tel: 0(533)7175954

e-mail:oekren@cu.edu.tr 